\title{
PEMETAAN DATA DAN VISUALISASI KEDALAMAN AIR PADA BENDUNGAN / WADUK
}

\author{
Bayu Rahayudi ${ }^{1}$, Marji $^{2}$ \\ ${ }^{12}$ Fakultas Ilmu Komputer, Universitas Brawijaya \\ Email: ${ }^{1}$ ubay1@ub.ac.id, ${ }^{2}$ marji@ub.ac.id
}

(Naskah masuk: 01 Maret 2017, diterima untuk diterbitkan: 07 Mei 2017)

\begin{abstract}
Abstrak
Penelitian dilakukan untuk melakukan pemetaan data dan visualisasi kedalaman air suatu waduk. Hasil dari pemetaan dan visualisasinya digunakan untuk mengetahui kontur endapan dan volume waduk. Pemetaan dilakukan dengan memprediksi titik-titik yang tidak diketahui kedalaman airnya berdasarkan titik-titik yang diketahui kedalaman airnya. Metode prediksi yang digunakan pada penelitian ini adalah metode interpolasi IDW (Inverse Distance Weighting), yaitu perhitungan rata-rata $\mathrm{n}$ buah titik, dimana titik-titik terdekat memiliki bobot pengaruh yang lebih besar dibandingkan titik-titik hasil pengukuran yang lebih jauh. Digunakannya metode ini bertujuan agar proses prediksi yang dilakukan dapat dilakukan dengan cepat, karena prediksi dilakukan untuk banyak titik-titik lain yang belum diketahui kedalaman airnya. Dari hasil penelitian diperoleh hasil bahwa jumlah titik yang paling baik digunakan untuk memprediksi titik yang tidak diketahui kedalaman airnya adalah sebanyak 5 buah titik terdekat. Data yang digunakan sebagai data percobaan pada penelitian ini adalah data pengukuran kedalaman air di waduk atau bendungan Wonorejo tahun 2004 dan tahun 2005. Hasil dari penelitian ini adalah suatu perangkat lunak yang digunakan untuk melakukan pemetaan dan memvisualisasikan kedalaman air di suatu waduk atau bendungan.
\end{abstract}

Kata kunci: visualisasi, pemetaan, interpolasi, inverse distance weighting (idw)

\begin{abstract}
Prediction has been widely used in every research and field. In water level visualization system, prediction can be used for measuring water level at the dam. From the measurement, can be known the dam contour and also its water volume. The prediction can be done by measuring water level at several certain points, and used the points to predict another unmeasure points. Prediction metode used in this research is inverse distance weighting (IDW) interpolation, which were using greater weighting on neaerer point than farther point. From this research known that using 5 nearest point will result optimum prediction. This metode is used in order to get faster result because of thousand prediction will be done. Data used in this research are water level measurement data of Wonorejo dam in 2004 and 2005. The result of this research is a program that can be used to map and visualize water level of a dam.
\end{abstract}

Keywords: visualization, mapping, interpolation, inverse distance weighting (idw)

\section{PENDAHULUAN}

Prediksi data telah banyak digunakan dalam berbagai bidang. Pada bidang ekonomi, prediksi dapat digunakan untuk memprediksi pertumbuhan ekonomi di masa mendatang. Di bidang demografi, prediksi data digunakan untuk memprediksi pertumbuhan penduduk di suatu wilayah tertentu. Demikian pula di bidang pengairan, prediksi data dapat digunakan untuk memprediksi kedalaman air di suatu waduk atau bendungan. Dari pengukuran kedalaman air tersebut dapat diketahui kontour dasar waduk atau bendungan tersebut, dan pada akhirnya dapat pula diketahui volume airnya.

Bendungan atau waduk adalah sarana vital yang salah satunya digunakan sebagai pengatur dan pengendali debit dan volume air yang mengalir di suatu daerah. Volume air yang dapat ditampung di suatu bendungan atau waduk dipengaruhi oleh tingginya endapan dan sedimentasi yang terjadi di dasarnya. Jika endapan dan sedimentasi di dasar bendungan atau waduk tersebut cukup banyak/tinggi, maka volume air yang dapat ditampung oleh bendungan atau waduk tersebut semakin berkurang, sehingga diperlukan tindakan lebih lanjut, misalnya dengan pengerukan endapan atau sedimentasi tersebut. Tinggi/banyaknya endapan atau sedimentasi di suatu bendungan atau waduk dapat diketahui dengan melaku-kan pengukuran kedalaman air di beberapa tempat.

Data kedalaman air yang diperoleh dari hasil pengukuran di suatu bendungan atau waduk, bukanlah data yang berukuran kecil, karena data kedalaman air tersebut diperoleh dari pengukuran terhadap beberapa puluh atau beberapa ratus titik pengukuran. Analisa terhadap kedalaman air, yang meliputi analisa ketinggian endapan atau sedimentasi pada dasar bendungan atau waduk, cukup sulit 
dilakukan jika hanya dengan melihat data-data pengukuran yang telah diperoleh. Dengan melakukan visualisasi dan pemetaan terhadap data kedalaman air yang diperoleh akan memudahkan petugas atau tenaga ahli yang bekerja untuk melakukan analisa terhadap kondisi yang terjadi pada bendungan atau waduk tersebut, misalnya dengan mengetahui volume air bendungan atau waduk, dan perkiraan terhadap ketinggian endapan atau sedimentasi yang terdapat di tempat atau area tertentu.

Penggunaan data pengukuran untuk melakukan pemetaan atau perhitungan belumlah mencukupi, karena untuk membuat pemetaan dan visualisasi data yang baik diperlukan data dalam jumlah besar. Jika dilakukan pengukuran untuk semua titik yang diperlukan, maka akan diperlukan waktu, tenaga dan biaya yang besar. Untuk itu diperlukan prediksi terhadap titik-titik yang tidak diketahui dengan memanfaatkan titik-titik hasil pengukuran. Metode prediksi yang digunakan dapat digunakan adalah metode interpolasi IDW (inverse distance weighting). Pada tahun 1999 metode ini digunakan untuk melakukan prediksi kandungan suatu tanah berdasarkan atas kandungan tanah yang ada di sekitarnya (Kravchenko,1999).

\subsection{Pengertian Visualisasi Dan Pemetaan}

Visualisasi didefinisikan sebagai suatu metode untuk merepresentasikan suatu data atau permasalahan ke dalam format grafik atau bentuk gambar yang mudah untuk dipahami. Sedangkan pemetaan adalah salah satu bentuk visualisasi, yaitu dengan merepresentasikan suatu data ke dalam suatu grafik dengan klasifikasi, misalnya peta. Salah satu bidang yang banyak berhubungan dengan visualisasi dan pemetaan adalah sistem informasi geografis (SIG) atau Geographic Information System (GIS) (Kang-tsung, 2006).

Roth (2015) melakukan penelitian dengan membandingkan beberapa perangkat lunak visualisasi pemetaan sistem air, untuk mengetahui perangkat lunak yang paling efisien di dalam melakukan visualisasi data dan perhitungan prediksi bencana yang dapat terjadi.

\subsection{Prediksi Data Spasial}

Prediksi data spasial adalah sebuah proses penentuan nilai yang belum diketahui atau nilai di masa mendatang menggunakan data yang telah dimiliki. Prediksi data spasial secara umum merupakan sebuah metode prediksi yang dapat menyatukan berbagai macam ketergantungan spasial. Proses ini digunakan dalam berbagai bidang seperti eksplorasi minyak, pertambangan, dan polusi air. Data yang tersedia untuk bidang ini berupa data pada lokasi-lokasi tertentu (seperti stasiun pengukuran di atas tanah maupun pengukuran dengan jarak tertentu di udara). Tujuan pemanfaatan proses prediksinya adalah untuk memprediksi nilai pada lokasi tertentu yang tidak mengalami pengukuran. Lokasi yang tidak diukur biasanya ditampilkan dalam bentuk grid biasa dan prediksi data digunakan untuk melakukan plot permukaan ataupun pembuatan peta garis batas (contour map).

Proses prediksi data yang dilakukan untuk area yang tidak mengalami pengukuran atau tidak memiliki data disebut sebagai spatio temporal prediction (Manolopoulos, et.al, 2005). Prediksi ini dapat dilakukan dengan menggunakan berbagai macam algoritma, dan yang paling sederhana dan mudah digunakan adalah dengan menggunakan interpolasi.

\subsection{Interpolasi}

Metode prediksi dengan interpolasi merupakan metode dasar yang banyak digunakan untuk melakukan pengolahan data seperti fungsi, kurva, dan proses serta perluasan informasi ke sebuah domain yang lebih luas. Perluasan ini hanya berupa perkiraan, dan ketepatannya tergantung pada berbagai faktor yang ada dalam proses perkiraan tersebut. Interpolasi sebagai sebuah alat dapat dilihat juga sebagai sebuah kasus untuk perkiraan fungsi penyebaran data. Proses perkiraan ini menggunakan batasan-batasan tertentu, sehingga sebuah perkiraan dapat dihasilkan dari interpolasi ketika batasan-batasan yang ada mengizinkan.

\subsection{Interpolasi Inverse Distance Weighting (IDW)}

Interpolasi Inverse Distance Weighting (IDW) adalah sebuah proses interpolasi yang berdasarkan asumsi bahwa nilai yang tersimpan pada lokasi terdekat, dengan lokasi yang akan dicari nilainya, memiliki pengaruh yang lebih besar terhadap nilai interpolasi dari pada nilai yang lokasinya lebih jauh (Armes, 2006; Kravchenko,1999). Metode ini menjadikan jarak dari nilai yang diketahui berbanding terbalik dengan pengaruh yang diberikan. Ketepatan nilai yang dihasilkan tergantung pada jumlah nilai yang digunakan dan jarak nilai yang dicari. Interpretasi IDW secara matematika didefinisikan seperti pada persamaan (1) :

$$
Z^{*}\left(x_{0}\right)=\sum_{i=1}^{n} w_{i} * Z\left(x_{i}\right)
$$

dimana $Z^{*}\left(x_{0}\right)$ adalah nilai yang dicari untuk lokasi $\mathrm{x}_{0}, \mathrm{Z}\left(\mathrm{x}_{\mathrm{i}}\right)$ adalah nilai-nilai di sekitar $\mathrm{Z} *\left(\mathrm{x}_{0}\right)$ yang digunakan sebagai data perhitungan, $\mathrm{W}_{\mathrm{i}}$ merupakan bobot jarak masing-masing titik terhadap nilai yang dicari, dan $\mathrm{n}$ merupakan jumlah titik yang akan digunakan (referensi). Jumlah nilai yang digunakan sebagai referensi bisa berjumlah tetap ataupun bervariasi. Dari persamaan (1) dapat diketahui bahwa 
data yang digunakan sebagai referensi harus diberi bobot. Pembobotan untuk setiap data yang digunakan dapat dihitung dengan menggunakan persamaan (2) :

$$
w_{i}=\frac{\frac{1}{d_{i}^{P}}}{\sum_{i=1}^{n} \frac{1}{d_{i}^{p}}}
$$

dimana $\mathrm{w}_{\mathrm{i}}$ adalah bobot untuk nilai ke-i, dimana merupakan jarak dari lokasi nilai ke-i dengan lokasi nilai yang dicari, dan $\mathrm{p}$ merupakan nilai parameter eksponensial untuk jarak titik ke i.

\section{METODE PENELITIAN}

Metode penelitian yang dilakukan meliputi proses pencarian dan perolehan data, dilanjutkan dengan perancangan basis data, kemudian dilakukan perancangan perangkat lunak. Data yang digunakan pada penelitian ini adalah data kedalaman air di suatu waduk (selama dua periode, 2004 dan 2005) yang diperoleh dari data kedalaman air waduk yang terdapat di salah satu bendungan atau waduk di propinsi Jawa Timur (bendungan Wonorejo). Data yang digunakan adalah data akhir (yang telah ada) yang diperoleh dari instansi terkait (Jasa Tirta), dan tidak dengan melakukan pengukuran kedalaman air secara mandiri. Data akhir tersebut adalah data hasil survey lapangan yang dilakukan secara berkala oleh petugas di bendungan atau waduk tersebut (Anonym, 2004).

Struktur basis data yang digunakan mengacu kepada struktur umum yang digunakan pada basis data geospatial, yaitu data spatial (keruangan) yang akan menyimpan data posisi (jarak vertikal atau y, dan jarak horisontal atau $\mathrm{x}$ ) dari titik-titik pengukuran, dan data atribut (deskripsi) yang akan menyimpan data kedalaman air pada titik-titik pengukuran yang telah ditentukan. Posisi titik-titik pengukuran (nilai $\mathrm{x}$ dan $\mathrm{y}$ ) dihitung dari suatu titik referensi pengukuran yang telah ditentukan, dimana nilai $\mathrm{x}$ adalah jarak horisontal titik pengukuran ke titik referensi, dan nilai y adalah jarak vertikal titik pengukuran ke titik referensi yang digunakan. Setiap data-data pengukuran akan disimpan ke dalam tabel, sehingga ketika ingin melakukan visualisasi dan pemetaan data berdasarkan pada data atau periode pengukuran tertentu, dapat dilakukan dengan membaca tabel yang sesuai.

Setelah basis data didesain dan algoritma prediksi yang digunakan telah ditentukan, kemudian dilakukan desain user interface dan proses interaksi yang diperlukan antara pengguna dengan sistem informasi yang dibuat. Proses interaksi yang dapat terjadi antara lain interaksi pemasukan data, manipulasi dan analisa data, dan interaksi untuk mendapatkan informasi dari hasil pemrosesan data (output). Interaksi pemasukan data, dibuat agar pengguna dapat memasukkan data-data pengukuran, yang meliputi lokasi pengukuran (nilai x dan y pengukuran dari titik referensinya), dan data kedalaman airnya. Agar proses penginputan data mudah dilakukan, maka proses inputnya dibuat dalam bentuk tabel (tabular). Proses pemetaan dan visualisasi data dapat dilakukan bila proses input data telah selesai dilakukan.

\section{HASIL DAN PEMBAHASAN}

\subsection{Deskripsi Sistem}

Sistem yang akan dibangun adalah sistem yang dapat melakukan penyajian data spasial ke dalam bentuk peta atau gambar dua dimensi. Data spasial yang digunakan adalah data spasial titik (point) yang berupa kedalaman air di suatu waduk hasil pengukuran lapangan.

\subsection{Diagram Alir Sistem}

Diagram alir sistem pada penelitian ini dapat dilihat pada gambar 4.1.

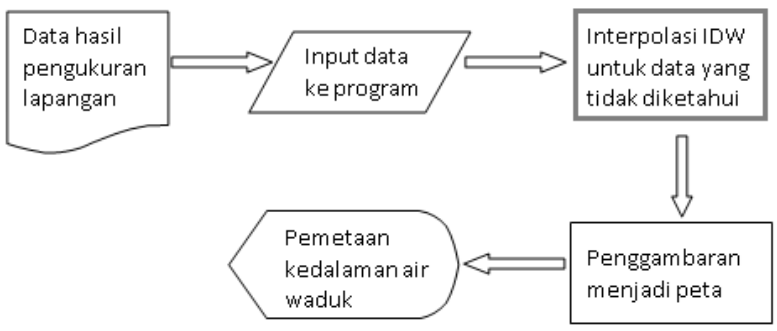

Gambar 1. Diagram alir dari sistem yang dibuat.

Diagram tersebut menjelaskan tentang proses prediksi sampai dengan pemetaan dari sistem yang dibuat.

Diagram alur data level 0 dari sistem yang dibuat dapat dilihat pada Gambar 2. Pada diagram alur data level 0 dijabarkan bahwa sistem memiliki tiga proses utama, yaitu manipulasi data, prediksi data dan visualisasi data. Pada proses manipulasi data dan prediksi data akan melibatkan media penyimpanan, yang dalam hal ini adalah database dbwaduk.

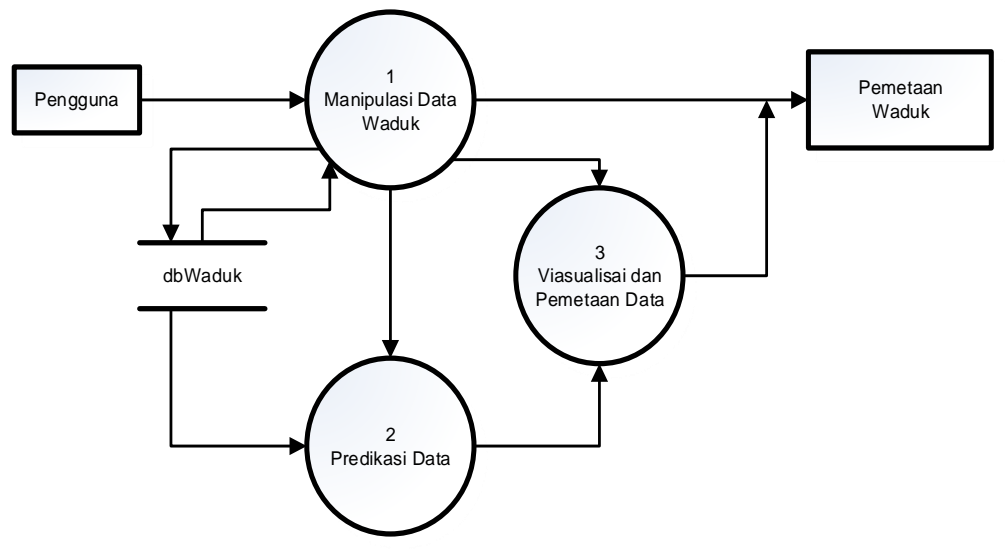

Gambar 2. Diagram level 0 dari sistem yang dibuat. 


\subsection{Pembuatan Basis Data}

Proses prediksi data dan pemetaan kedalaman air waduk yang dilakukan dalam penelitian ini memerlukan data waduk serta data kedalaman air hasil pengukuran lapangan. Data waduk yang digunakan antara lain nama waduk, lokasi waduk, daya tampung maksimum dan efektif dari waduk.

Dapat pula ditambahkan keterangan-keterangan lain tentang waduk sebagai informasi pelengkap. Sedangkan dat kedalaman air yang digunakan adalah data lokasi dalam bentuk absis, ordinat, dan elevasi air.

Berdasarkan kebutuhan data tersebut, maka dibuat tabel yang dapat menampung data-data tersebut. Setelah dilakukan analisa kebutuhan, maka dibentuk beberapa tabel, yaitu tabel waduk, tabel lokasi_point, tabel cross_point, tabel ukur_lapang, tabel spatial_data_saver. Tabel-tabel ini digunakan untuk menyimpan seluruh data hasil pengolahan data lapang yang akan dijadikan data acuan untuk proses prediksi dan pemetaan kedalaman air waduk

Tabel waduk menyimpan data yang berkaitan dengan keterangan waduk seperti nama waduk, lokasi wauk, tahun peresmian, level air, dan daya tampung waduk. Tabel lokasi_patok menyimpan data lokasi patok yang digunakan sebagai titik acuan untuk pengukuran melintang. Tabel ini menyimpan nama patok, lokasi patok, dan ketinggian patok. Tabel cross_point menyimpan data pasangan patok yang digunakan untuk pengukuran melintang kedalaman air waduk. Tabel ini berisi nama cross point, patok awal, patok akhir dan jarak antar patok. Tabel ukur_lapang menyimpan data kedalaman air dan lokasi pengukuran hasil pengukuran lapangan. Data ini meliputi data cross point pengukuran, tahun pengukuran, jarak ukur dari patok awal, dan kedalaman air. Tabel ini digunakan untuk menyimpan dokumentasi data hasil pengukuran lapangan. Tabel penyimpanan data spasial (spatial data saver) menyimpan data spasial hasil pengolahan data lapang yang telah diubah dalam bentuk titik $\mathrm{x}, \mathrm{y}, \mathrm{z}$ dan tahun pengukuran. Data spasial tersebut merepresentasikan lokasi pengukuran dan kedalaman air. Struktur dan relasi antar tabel dapat digambarkan seperti pada Gambar 3.

\subsection{Prediksi Data}

Inverse Ditance Weigthing (IDW) merupakan metode interpolasi yang memanfaatkan bobot dan nilai dari masing-masing data referensi yang berada di sekitar titik yang dicari untuk menentukan nilai yang tidak diketahui tersebut. Langkah-langkah yang dilakukan untuk melakukan prediksi adalah sebagai berikut :

1. Menentukan lokasi titik yang belum memiliki nilai kedalaman air.

2. Menentukan nilai-nilai di sekitar titik yang dicari dengan jumlah tertentu.
3. Menentukan jarak dan bobot dari masing-masing data referensi menggunakan persamaan bobot untuk IDW.

4. Penentuan bobot ini menggunakan parameter eksponensial dengan nilai 2.

5. Setelah bobot dari masing-masing data referensi diperoleh, proses prediksi data dilaksanakan.

Hasil prediksi kemudian dipetakan ke dalam bentuk gambar melalui proses pemetaan.

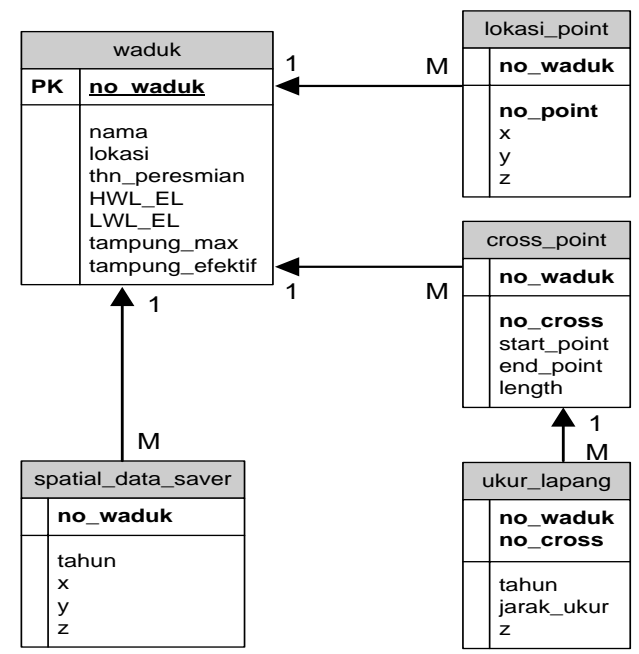

Gambar 3. Struktur dan relasi antar tabel.

Data kedalaman air waduk hasil pengukuran lapang berupa jarak lokasi pengukuran dengan titik acuan dan kedalaman air. Data ini dikonversi menjadi data spasial berbentuk titik (point) dengan x,y untuk lokasi dan z untuk kedalaman air. Data spasial hasil konversi digunakan sebagai data referensi untuk prediksi kedalaman air di seluruh area waduk.

Prediksi data kedalaman air dilakukan dengan menggunakan sejumlah titik referensi tertentu. Evaluasi dilakukan terhadap sejumlah titik referensi yang berbeda untuk mengetahui tingkat ketepatan dan tingkat kesalahan prediksi data. Jumlah titik referensi yang dievaluasi yaitu 5, 10, 15, 20, 25 dan 30 dengan parameter eksponensial 2.

\subsection{Pemetaan Data}

Pemetaan data merupakan bagian yang memanfaatkan proses prediksi data. Nilai-nilai yang dihasilkan dari proses prediksi kemudian ditampilkan ke layar dengan memanfaatkan library grafik dari OpenGL dengan memanfaatkan obyek point dan triangel. Proses pemetaan ini dilakukan untuk seluruh area waduk untuk penggambaran data dengan jarak tertentu.

Proses pemetaan hasil prediksi data tersebut dapat dijelaskan dalam langkah-langkah sebagai berikut :

1. Penentuan jarak pemetaan setiap data untuk mendapatkan detail data dan gambar. 
2. Penentuan jumlah titik referensi untuk proses prediksi

3. Dilakukan prediksi untuk semua titik yang diperlukan untuk proses pemetaan dan menyimpannya ke dalam tabel sementara (spatial data saver)

4. Gambar ke dalam bentuk triangle untuk semua titik pengukuran dan perhitungan yang diperoleh.

5. Pengulangan proses pemetaan jika diinginkan tingkat ketelitian yang berbeda

Hasil prediksi data dengan menggunakan jumlah titik referensi dengan tingkat kesalahan terkecil dipetakan menggunakan fasilitas pustaka OpenGL. Proses ini dilakukan untuk menampilkan data hasil prediksi dalam bentuk peta dua dimensi menggunakan primitif triangle strip. Setiap data kedalaman air direpresentasikan dengan warna untuk menunjukkan nilai kedalaman air dalam peta. Area perairan waduk dipetakan dengan warna biru untuk air dalam dan biru muda untuk air dangkal sedangkan area di luar perairan dipetakan dengan warna hijau dan kuning.

\subsection{Evaluasi Hasil Pemetaan Data}

Evaluasi dilakukan dengan membandingkan hasil prediksi dengan menggunakan $\mathrm{n}$ jumlah titik referensi yang berbeda-beda, dengan nilai $\mathrm{n}$ adalah 5 , $10,15,25$ dan 30. Berdasarkan hasil evaluasi tersebut, nilai kesalahan terkecil untuk prediksi yang diuji yaitu terdapat pada penggunaan 5 data referensi terdekat dengan menggunakan data kedalaman air waduk.

Ternyata semakin besar jumlah data referensi yang digunakan menyebabkan tingkat kesalahan semakin besar sehingga ketepatan prediksi data berkurang. Hal ini disebabkan semakin banyaknya data yang berpengaruh dan nilai yang berpengaruh semakin bervariasi. Hasil prediksi dengan menggunakan data referensi semakin banyak menghasilkan nilai yang semakin berbeda dengan nilai sebenarnya.

Hasil prediksi dan pemetaan dengan menggunakan 5 buah titik referensi dapat dilihat pada gambar 4. Warna kuning (terang) menunjukkan daerah yang sangat dangkal, sedangkan yang berwarna biru tua (gelap) menunjukkan daerah yang dalam. Dari hasil prediksi, pemetaan dan visualisasi tersebut dapat diketahui kondisi daerah yang memiliki area yang dangkal dan dalam, dan juga daerahdaerah yang memiliki endapan yang tinggi.

\section{KESIMPULAN}

Dari penelitian yang telah dilakukan dapat dibuat kesimpulan sebagai berikut :

1. Pemetaan dan visualisasi dapat dilakukan terhadap hasil pengukuran lapangan dari kedalaman air dari suatu waduk, sehingga dapat diperoleh hasil analisis yang lebih baik dan lebih mudah untuk dipahami.

2. Di dalam melakukan pemetaan dan visualisasi data kedalaman air suatu waduk perlu dilakukan prediksi terhadap titik-titik yang tidak dilakukan pengukuran terhadapnya. Untuk itu dapat digunakan metode prediksi interpolasi yang sederhana. Digunakannya metode ini karena proses prediksi dapat dilakukan dengan cepat, mengingat titik-titik yang diprediksi jumlahnya cukup banyak.

3. Metode Interpolasi Inverse Distance Weighting (IDW) berdasarkan tingkat ketepatan prediksi data dapat digunakan untuk memprediksikan data spasial yang berupa data kedalaman air waduk. Hasil prediksi data yang berupa data lokasi dan kedalaman air dapat ditampilkan dalam bentuk peta dua dimensi menggunakan metode grafik OpenGL dengan primitif triangle strip. Jumlah data referensi yang dapat digunakan dalam metode ini yaitu sebanyak 5 data referensi dengan data referensi yang bersifat linear.

4. Semakin besar jumlah data referensi yang digunakan, semakin besar tingkat kesalahan yang dihasilkan sehingga ketepatan prediksi data berkurang.

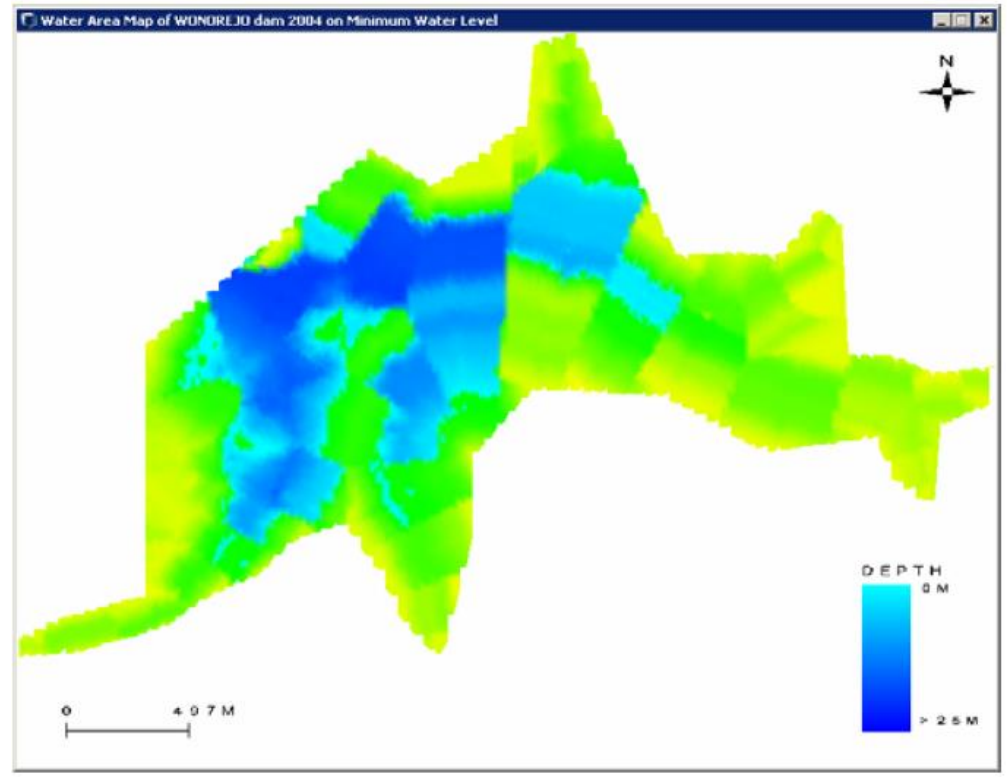

Gambar 4. Hasil prediksi dan pemetaan dengan menggunakan 5 titik referensi.

\section{DAFTAR PUSTAKA}

ANONYM, 2004, Laporan Echo Sounding Waduk Wonorejo, Divisi Jasa Air dan Sumber Air, Perum Jasa Tirta I, Malang. 
116 Jurnal Teknologi Informasi dan Ilmu Komputer (JTIIK), Vol. 4, No. 2, Juni 2017, hlm. 111-116

ARMES, C.J., 2006, Spatial Prediction of Soil Penetration Resistance using Geographic Information Systems, Centre of Excellence - GIS Laboratory, Lincoln University, Missouri.

KRAVCHENKO AND G. BULLOCK, 1999, Comparative Study of Interpolation Method for Mapping Soil Properties, Agron Journal, 91: 393-400.

KANG-TSUNG， C., 2006, Introduction to Geographic Information Systems, McGrawHill.

MANOLOPOULOS, Y., PAPADOPOULOS, A. N., AND VASSILAKOPOULOS, M. GR., 2005, Spatial Databases: Technologies, Techniques, and Trends, Idea Group Publishing.

ROTH RE, C QUINN, AND D HART, 2015, The competitive analysis method for evaluating water level visualization tools, In: A. Vondrakova, J. Brus, and V. Vozenilek (eds) Modern Trends in Cartograph Lecture Notes in Geoinformation and Cartography, Chapter 19: 241-256 